\title{
Antifungal protein determination for submerged cultures of the medicinal mushroom Ganoderma lucidum (Ganodermataceae) with activity over the phytopathogen fungus Mycosphaerella fijiensis (Mycosphaerellaceae)
}

Determinación de proteínas antifúngicas de cultivos sumergidos del hongo medicinal Ganoderma lucidum (Ganodermataceae) con actividad sobre el hongo fitopatógeno Mycosphaerella fijiensis (Mycosphaerellaceae)

Monica A. Arias-Londoño ${ }^{1,3^{*}}$, Paola A. Zapata-Ocampo ${ }^{2,3}$, Angela R. Mosquera-Arevalo ${ }^{1}$, Jaiver D. Sanchez-Torres ${ }^{3}$, Lucía Atehortua-Garcés ${ }^{1}$

\begin{abstract}
Banana is one of the most important edible crops in the world, however, it's attacked by different pathogens, one of the most prominent of these is the fungus Mycosphaerella fijiensis, causal agent of Black Sigatoka. The environmental and economic issues related to the pesticides used for its control have encouraged the search for cleaner alternative biomolecules. Previous studies were made by the Biotechnology group from the Universidad de Antioquia searching for a biological alternative for the control of M. fijiensis; in these the antifungal capacity of the fungus Ganoderma lucidum was determined as an antagonist and then as a source of protein extracts with inhibitory activity in vitro and in greenhouse plants; these findings were the foundation of this work, which focuses in the study of the enzymatic capacity of the proteins present in the protein extracts, due to their potential ability to degrade different compounds, including polysaccharides, lipids, peptides and nucleic acids, constituents of essential parts of a living cell; therefore these extracts can act as possible antifungal agents. In this study, protein extracts of $G$. lucidum obtained from bioreactor cultures (BIOFLO $110^{\circledR}$ ) were characterized in terms of their deoxyribonuclease, ribonuclease, protease, glucanase and chitinase enzymatic activities. The extracts were also fractionated and each fraction obtained was evaluated for its inhibitory capacity against the phytopathogen fungus M. fijiensis, and through mass spectrometry analysis the presence of different enzymes with antifungal potential was confirmed.
\end{abstract}

Keywords: Chitinase, fungicide, Ganoderma lucidum, glucanase, nuclease, protease, Sigatoka

\section{Resumen}

El banano es uno de los cultivos comestibles más importante en el mundo, sin embargo, es atacado por diferentes patógenos, uno de los más destacados es el hongo Mycosphaerella fijiensis, agente causal de la Sigatoka Negra. Los problemas ambientales y económicos relacionados con los pesticidas usados para su control han estimulado la búsqueda de biomoléculas alternativas no contaminantes. En el grupo de Biotecnología de la Universidad de Antioquia se realizaron estudios previos buscando una alternativa biológica al control de M. fijiensis, en los cuales se determinó la capacidad antifúngica del hongo Ganoderma lucidum como antagonista y posteriormente como fuente de extractos proteicos con actividad inhibitoria in vitro y

\footnotetext{
1. Laboratorio de Biotecnología, Universidad de Antioquia, Medellín, Colombia.

2. Facultad de Ciencias y Biotecnología, Universidad CES, Medellín, Colombia.

3. Centro de Investigaciones del Banano (CENIBANANO)-AUGURA.

* Autor de correspondencia: <monica.arias@udea.edu.co>
} 
en plantas de invernadero; estos hallazgos fueron la base de este trabajo, que está enfocado en el estudio de la capacidad enzimática de las proteínas presentes en los extractos proteicos, debido a su capacidad potencial para degradar diferentes compuestos, incluyendo polisacáridos, lípidos, péptidos y ácidos nucleicos, que constituyen partes esenciales de una célula viva; por lo tanto, estos extractos pueden actuar como posibles agentes antifúngicos. En este estudio, los extractos proteicos de $G$. lucidum obtenidos a partir de cultivos en biorreactor (BIOFLO $110^{\circledR}$ ) fueron caracterizados en términos de sus actividades enzimáticas: deoxyribonucleasa, ribonucleasa, proteasa, glucanasa y quitinasa. Los extractos también fueron fraccionados y cada fracción obtenida fue evaluada para la capacidad inhibitoria contra el hongo fitopatógeno $M$. fijiensis, y a través de los análisis de espectrometría de masas se confirmó la presencia de diferentes enzimas con potencial antifúngico.

Palabras claves: Quitinasa, fungicida, Ganoderma lucidum, glucanasa, nucleasa, proteasa, Sigatoka

\section{INTRODUCTION}

Banana is one of the most important crops around the world, it is a staple in the diet of millions of people in addition to contributing significantly to the export income of less developed countries around the world (FAO 2011, 2014). However, banana production is affected by different pathogens; one of the most persistent is the Ascomycete fungus Mycosphaerella fijiensis M. Morelet, cause of the Black Sigatoka disease (Churchill 2011, Marín et al. 2003). The cost of chemical control of this disease and its impact on non-target species has led to the search for new molecules and strategies that are more specific and sustainable (Arzate et al. 2006, Ayala et al. 2014, Ceballos et al. 2012, EPA 2005, Martinez et al. 2005, Niño et al. 2011, Osorio 2006, Viveros and Castaño 2006). Antifungal proteins appear as potential control agents due to their substrate specificity (i.e chitin, peptides, glucans) and diversity that allows them to cleave or modify different cellular components of an organism (i.e phytopathogens) (Fernández et al. 2011, Hegedüs and Marx 2013, Ngai et al. 2005, Wong et al. 2010). In this study we have focused on the mushroom Ganoderma lucidum (Curtis) P. Karst., a lignolytic fungus traditionally known for its medicinal properties (Ansor et al. 2013, Manavalan et al. 2015, Paterson 2006, Suarez et al. 2013). We report the inhibitory effect of G. lucidum protein extracts over $M$. fijiensis growth and also determined its enzymatic DNase, RNase, glucanase, protease and chitinase activities, and the presence of potential antifungal proteins in order to elucidate the possible mechanism responsible for the growth inhibitory activity.

\section{MATERIALS AND METHODS}

\section{Organisms and growth conditions}

Ganoderma lucidum (Curtis) P. Karst cultivation. A G. lucidum (Curtis) P. Karst strain, donated by Dr. Shu-Ting Chang from the University of Hong Kong to the Biotechnology Laboratory of the Universidad de Antioquia, was used in this study. The culture was preserved on FC1 agar (Sacarose, yeast extract, barley flour and agar).

The biomass used for protein extraction was obtained from Bioreactor cultures, which were prepared by inoculation of $4.5 \mathrm{~L}$ of culture medium reported by (Zapata et al. 2009) in a seven liter BIOFLO $11{ }^{\circledR}$ Bioreactor by $0.1 \% \mathrm{w} / \mathrm{v}$ of pre-inoculum and incubated at a temperature of $25{ }^{\circ} \mathrm{C} \pm 1{ }^{\circ} \mathrm{C}$ under constant agitation at $150 \mathrm{rpm}$ and blue light over 5 days (Zapata et al. 2009).

Mycosphaerella fijiensis M. Morelet cultivation and identification. Three $M$. fijiensis isolates were obtained from infected banana leaves from the Urabá region in Colombia provided by The Colombian Banana Growers Association (AUGURA), through the isolation of monosporic cultures that were incubated in PDA at $25{ }^{\circ} \mathrm{C}$ in the darkness for over 30 days before their subcultivation. The isolates were identified using the Internal transcribed spacer regions 1/2 (ITS) (Johanson and Jeger 1993) and actin (ACT) primers. The sequences were aligned in BlastN and the analysis was made using the software MEGA 6.0.

Protein isolation from G. lucidum. The biomass 
was kept in plastic bags at $-20{ }^{\circ} \mathrm{C}$, for seven days. The bags were thawed, and the recovered biomass was washed with PBS $\mathrm{pH} 7.4,1.5 \mathrm{mM}$ and filtered through a membrane of $50 \mathrm{~mm}$ using a vacuum pump, and proteins were extracted using mechanic lysis following previous reports (Crowell et al. 2013, LaMontagne et al. 2016). The protein extracts were then incubated overnight at $4{ }^{\circ} \mathrm{C}$ before their use.

Three independent experiments were carried out and biological replicates were pooled to minimize biological variation. Protein content was measured using the Bradford method with bovine serum albumin BioRad ${ }^{\circledR}$ as the standard (Bradford 1976, Crowell et al. 2013).

Enzyme assays. All enzymatic assays were carried out using the extracts obtained from G. lucidum submerged cultures biomass. All assays were performed in triplicate and the mean values calculated. Spectrophotometric methods were used to determine glucanase (Jijakli and Lepoivre 1998, Liang et al. 1995), chitinase (Cretoiu et al. 2012), protease (Gabarro et al. 2016, Tian et al. 2004), deoxyribonuclease (Kunitz 1946) and ribonuclease (Kalnitsky et al. 1958, Kunitz 1946) activities.

\section{Fractionation}

Preparative isoelectric focusing and Polyacrylamide gel electrophoresis (SDS-PAGE). Isoelectric focusing (IEF) was performed on the mini Bio-Rad Rotofor preparative IEF system (Bio-Rad Laboratories Ltd., Hemel Hempstead, UK). After the completion of the preparative IEF run, the fractions were harvested and assayed for antifungal activity (Khalyfa et al. 1993, O'Loughlin et al. 2014), and sodium dodecyl sulfate (SDS)-PAGE was performed according to the method of Laemmli. The gels were stained with silver nitrate $\left(\right.$ Amresco $\left.{ }^{\circledR}\right)$ (Chevalier 2010, Laemmli 1970).

Assay for fractions' antifungal activity. The inhibition tests were performed based on the CLSI method M38-A2 for fungi susceptibility to antifungals (CLSI 2009).

\section{Statistical analysis}

A totally random design (TRD) was performed with twenty experimental units. Statistical analyses included parametric tests and ANOVA (Montgomery 2012) using GraphPad Prism 6 software.

\section{Mass spectrometry identification}

Trypsin digestion and LC-MS/MS. Gel plugs were washed twice using $500 \mu \mathrm{L}$ of HPLC grade water and $500 \mu \mathrm{L}$ of acetonitrile (ACN) $50 / 50 \mathrm{ACN} /$ $25 \mathrm{mM}$ ammonium bicarbonate (AMBIC). The gel plugs were first dehydrated, reduced, vacuum dried and digested with trypsin. Lastly, the trypsin was removed, and the samples were washed with $25 \mathrm{mM}$ AMBIC. Every tube was analyzed independently (Lapolla et al. 2004). The extracted peptides were analyzed in a MALDI-TOF-TOF Proteomics Analyzer. The mass spectra were processed and identified using MASCOT 2.0 (Dekroon et al. 2011).

\section{RESULTS}

\section{Organisms and growth conditions}

Ganoderma lucidum cultivation. For all the batches cultivated an average of $54.3 \mathrm{~g} / \mathrm{L}$ of $G$. lucidum wet biomass was obtained per batch after 5 days of incubation under the determined conditions (table).

Tabla. Average values of biomass concentration, protein concentration and enzymatic activities.

\begin{tabular}{|c|c|c|c|c|c|c|c|}
\hline $\begin{array}{l}\text { Biomass } \\
(\mathrm{g} / \mathrm{L})\end{array}$ & $\begin{array}{l}\text { Protein } \\
\text { concen- } \\
\text { tration } \\
(\mathrm{mg} / \mathrm{mL})\end{array}$ & $\begin{array}{l}\text { Protease (Abs } \\
\text { 450) }\end{array}$ & $\begin{array}{l}\text { Glucanase } \\
(\mu \mathrm{mol} \cdot \mathrm{min} / \mathrm{mL})\end{array}$ & $\begin{array}{l}\text { Chitinase } \\
\text { (Chitobiosi- } \\
\text { dase U/mL) }\end{array}$ & $\begin{array}{l}\text { Chitinase (Glu- } \\
\text { cosaminidase } \\
\mathrm{U} / \mathrm{mL} \text { ) }\end{array}$ & $\begin{array}{l}\text { RNase activ- } \\
\text { ity }(\mathrm{U} / \mathrm{mg})\end{array}$ & $\begin{array}{l}\text { DNase activity } \\
(\mathrm{U} / \mathrm{mg})\end{array}$ \\
\hline $54.3 \pm 1.97$ & $2.5 \pm 0.02$ & $0.610 \pm 0.011$ & $6.52 \pm 0.02$ & $0.053 \pm 0.002$ & $0.063 \pm 0.00001$ & $760 \pm 10$ & $0.076 \pm 0.018$ \\
\hline
\end{tabular}


Mycosphaerella fijiensis cultivation and identification. After thirty days of cultivation, colonies of five centimeters were obtained; the three isolates were satisfactorily identified as $M$. fijiensis.

Protein isolation from G. lucidum. The protocol allowed us to obtain approximately $2.5 \mathrm{mg} / \mathrm{mL}$ of soluble protein, starting with twenty grams of wet biomass; these extracts were used for the activity assays consistently.

Enzymatic assays. All of the enzymatic assays performed turned positive, indicating the presence of peptidases, $\beta$ glucanases, chitinases (chitobiosidases and glucosaminidases), ribonucleases and deoxyribonucleases (table).

Chitinase activity. For every extraction evaluated, the chitobiosidase test indicated that the G. lucidum extract showed an activity three times higher when compared to the control chitinase corresponding to $0.053 \mathrm{U} / \mathrm{mL}$, whereas for the glucosaminidase test the G. lucidum protein extract had half the activity of the control chitinase $(0.063 \mathrm{U} / \mathrm{mL})$. However, on average the glucosaminidase and chitobiosidase activity values are close $(0.05-0.06 \mathrm{U} / \mathrm{mL})$ (table).

Protease activity. All the extractions performed presented proteolytic activity under the conditions assayed, besides, under the concentrations tested (table) the commercial trypsin showed an activity 2.6 times higher than the succinylated casein, which had an activity corresponding to an absorbance of 0.610 at $405 \mathrm{~nm}$ when a concentration of $600 \mathrm{ppm}$ was used, as it is shown in the table.

Deoxyribonuclease activity. The results of the DNase activity assay revealed that $125 \mathrm{mg} / \mathrm{mL}$ (dilution 1:20 of the concentrated extract) of protein extract caused an increase in absorbance of $0.003 / \mathrm{min}$, showing a specific activity of $0.076 \mathrm{Kunitz} \mathrm{U} / \mathrm{mg}$ (table), which was much lower compared to the commercial DNase I activity used as control.

Ribonuclease activity. The extract showed a specific activity of $760 \mathrm{Kunitz} \mathrm{U} / \mathrm{mg}$, which was much lower compared to the commercial RNase A activity, however, the negative control did not show an increase at A260 either.

Glucanase activity. With regard to the $\beta-1,3-$ glucanase activity, the assay indicated a maximum of $6.5 \mathrm{U}(\mu \mathrm{mol} \cdot \mathrm{min} / \mathrm{mL})$ (table), although the activity was much lower compared to one from the control enzyme used.

Preparative isoelectric focusing fractionation. A correlation was observed between fractions and $\mathrm{pH}$, indicating an accurate separation on the Rotofor (figure $\square$ ). Interestingly, the range of the isoelectric points where most of the proteins were located was between 3 and 6 , though few proteins were found in the range of 6 to 10. The molecular weight of the proteins ranged from 6 to $113 \mathrm{kDa}$.

Antifungal assay. The highest growth inhibition percentages corresponded to fractions with isoelectric points (IP) between three and five, which had an average of $55 \%$, and the ones with IP nine and ten, which had inhibition percentages of around $79 \%$, indicating the presence of diverse active proteins (figure [).

\section{Fraction vs. pH}

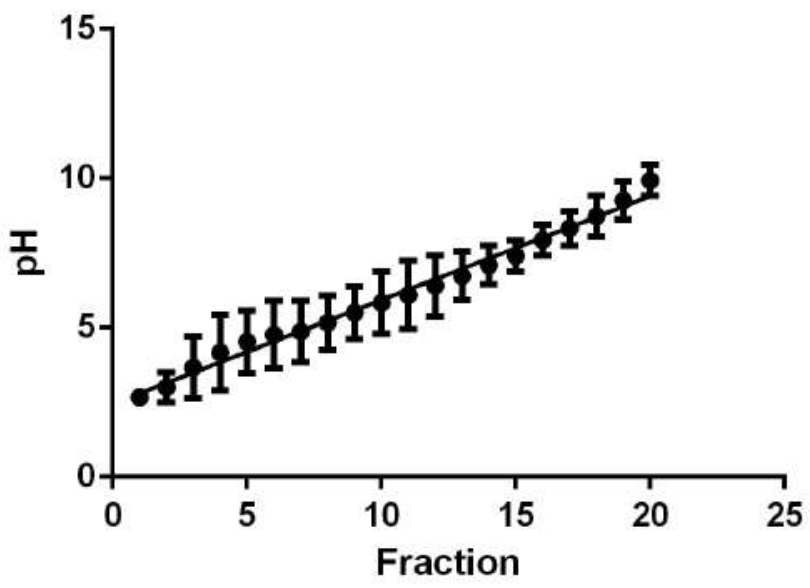

Figure 1. $\mathrm{pH}$ distribution of every fraction after isoelectro focusing.

Functional classification of the identified proteins. From the proteomic study performed, 46 identified proteins were chosen as potential antifungal candidates; they were classified in 33 functional 


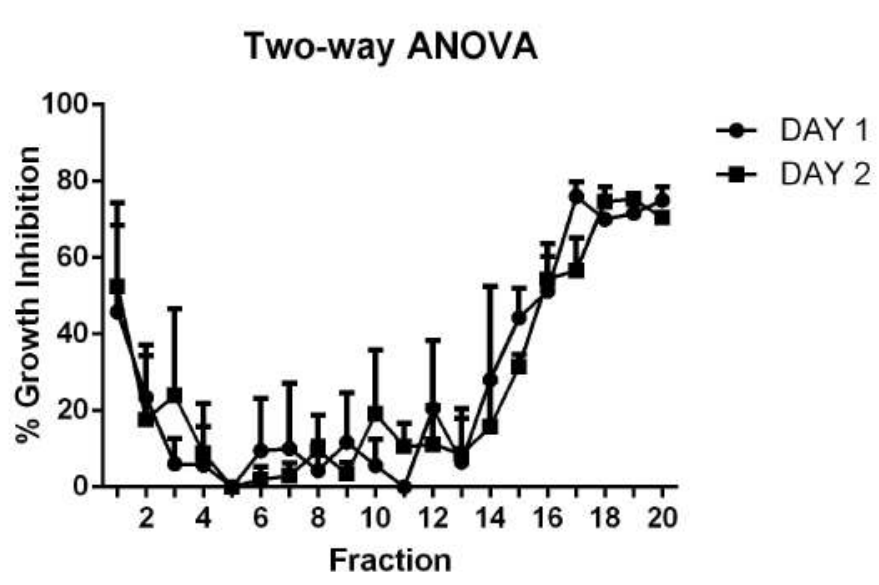

Figure 2. Antifungal microplate assay, growth inhibition percentage for every fraction.

categories (figure B]) according to biological roles that could be implied in their antifungal activity. Figure 5 depicts the functional classification that was sub-grouped into peptidases $(11.11 \%)$, glycoside hydrolases $(58.59 \%)$, glucanases $(13.13 \%)$, chitinases (9.09\%), RNases (4.04\%) and DNases (4.04\%).

\section{DISCUSSION}

Currently the limitations of biological antifungal compounds and the negative impact on the environment of the current chemical ones have spurred an urgent need for the development of alternative means that could meet future demands of pest control. We detected 46 potential antifungal proteins and classified them in five groups based on enzymatic mechanisms that could be involved in the growth inhibition process, these groups were chitinases, proteases, glucanases, deoxyribonucleases and ribonucleases, their presence was confirmed with the enzymatic tests and mass spectrometry analysis performed. An additional group, with a higher number of proteins, was found in the mass spectrometry analysis, it corresponded to glycosyl hydrolase, which includes chitinases, glucanases, glycosyltransferases, hexamidases and exo-1,3- $\beta$-glucanases (figure $\mathbf{3}$ ).

Only one antifungal protein has been isolated from G. lucidum, it is called Ganodermin and exerted in vitro antifungal action on the phytopathogen fungi
Botrytis cinerea, Physalospora piricola and Fusarium oxysporum (Wang and Ng 2006). Other proteins have been characterized from G. lucidum, but their antifungal activity has not been studied, and thus our study suggests for the first time the relationship between active proteins derived from G. lucidum submerged cultures and their antifungal potential towards the phytopathogenic fungus of the banana plant $M$. fijiensis Morelet.

\section{Identification of proteins involved in chitin hy- drolysis}

Though a few studies have made reports about $G$. lucidum-derived chitinases (Manavalan et al. 2015, Yu et al. 2015), our analysis reveals the identification of five different chitinases, three of which are presumed to have chitin binding capability. This information was complemented with the enzymatic tests, which indicated the presence of exochitinases, enzymes able to catalyze the progressive release of acetylchitobiose and $\mathrm{N}$-acetylglucosamine from the non-reducing end of chitin. Other fungi have chitinases with antifungal activity, this is the case of Penicillium ochrochloron, whose antifungal activity against Aspergillus niger and $F$. oxysporum was superior when using purified chitinase, and exhibited a chitinolytic activity of $60.04 \pm 0.12 \mathrm{U} / \mathrm{mL}$ over chitobiose and an activity of $53.84 \pm 0.22 \mathrm{U} / \mathrm{mL}$ over glucosamine (Patil et al. 2013), these values are higher compared to the ones obtained in this study (table), however this was a purified enzyme (Adams 2004). In another study one antifungal chitinase was isolated from $A$. niger LOCK 62 (Brzezinska and Jankiewicz 2012), obtaining a specific activity of $9.46 \mathrm{U} / \mathrm{mg}$. Crude and purified chitinase was evaluated against F. culmorum, F. solani and Rhizoctonia solani. The growth of $F$. solani was strongly inhibited by crude chitinase (73\%); the growth of B. cinerea, Alternaria alternata and $F$. oxysporum was not inhibited. Compared to our results this chitinase activity is higher and the antifungal activity is a comparable, since we observed values around $80 \%$ (figure [2).

\section{Identification of proteins involved in peptide degradation}

Proteins are important components of membranes in addition to being important structural and catalytic 


\section{GO (Molecular function)}

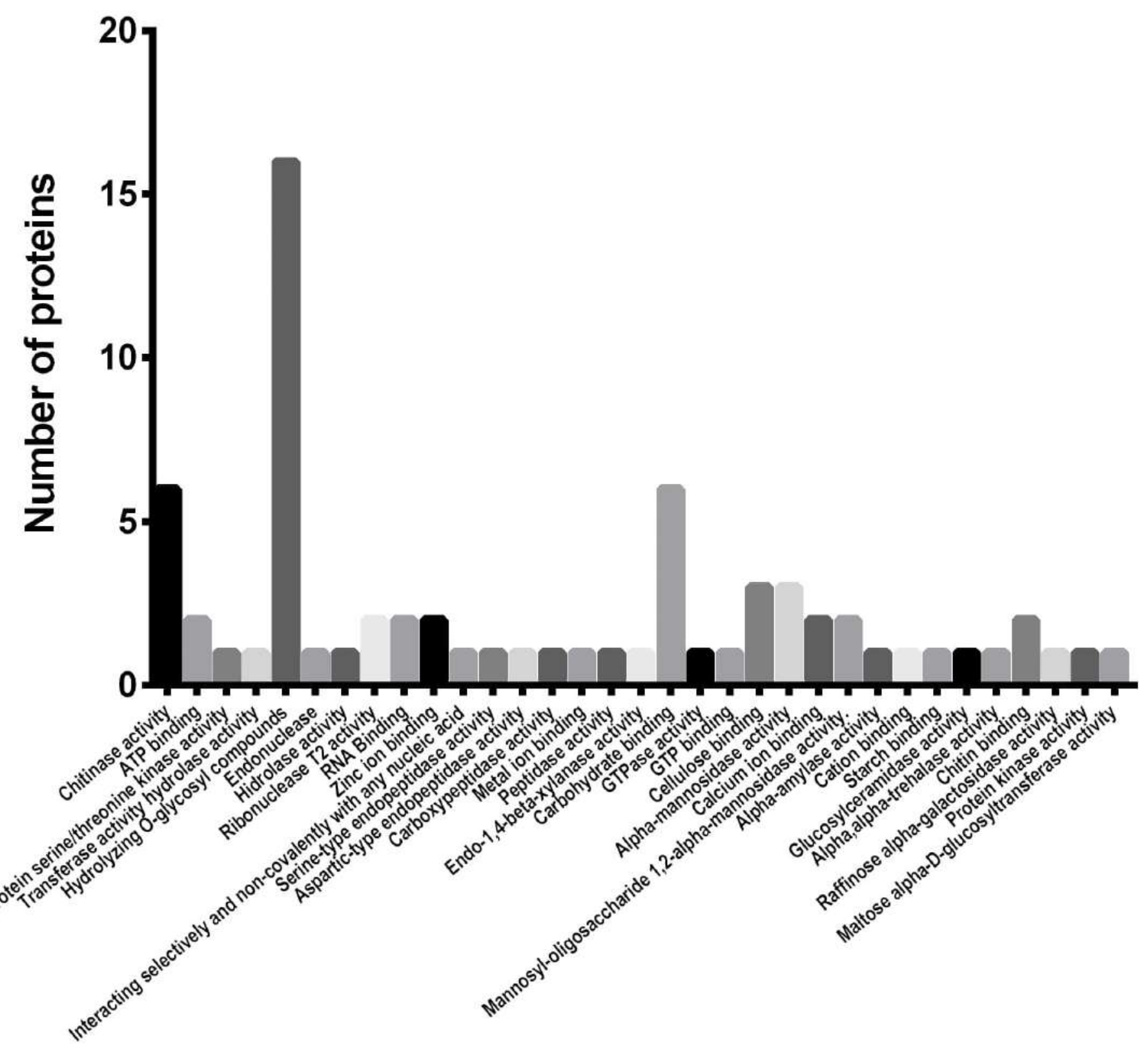

Figure 3. Bar chart depicting the identified proteins possibly related to antifungal activity of G. lucidum. Representation of proteins classified according to their function gene ontology (GO) category. 
metabolic agents for cells. In this study, a positive protease activity was observed and the presence of five different kinds of proteases was found (Aspartyl peptidase with zinc ion binding, serine endopeptidase, aspartic endopeptidase, glutamate carboxypeptidase II and a peptide hydrolase with metal ion binding domain) (Rawlings and Barrett 2014, Yike 2011), inferring a possible involvement in the degradation of membrane proteins, which could cause a breakdown of them, or even of relevant metabolic inner peptides (Yike 2011). Compared to other studies, the occurrence of this kind of enzymes in different species of mushroom can also be related to their participation in binding to the carbon source matrix and to the plant-pathogen process interaction itself (Inacio et al. 2015). In the specific case of $M$. fijiensis growth inhibition experienced in this study, peptidases appeared acting like potential dissolvers of some membrane proteins, since the membrane seemed to be collapsed inside the hyphae (figure 4 ). Currently few proteases obtained from mushrooms have been reported to show antifungal activity, one example is the study conducted with the fungus Aureobasidium pullulans (Banani et al. 2014), from which a purified alkaline serine protease with inhibitory activity up to $90 \%$ over the spore formation of the phytopathogen fungi Monilinia laxa, B. cinerea and $P$. expansum and maximum proteolytic activity of $100 \mathrm{U}$ was isolated, a value higher than the one found in this study $0.610 \mathrm{U} / \mathrm{mg}$ (table). In another study, fungal isolates from Piper hispidum Sw, showed that their proteases reduced the growth of the phytopathogen fungi $A$. alternata, Colletotrichum sp., Phyllosticta citricarpa and Moniliophthora perniciosa by approximately 54 to $65 \%$ (Orlandelli et al. 2015), values lower than the ones we were able to obtain over $M$. fijiensis Morelet (figure $\nabla$ ).

\section{Identification of proteins involved in nucleic acids degradation}

We found two deoxyribonucleases, one of them is an endonuclease that catalyzes the hydrolysis of ester linkages within nucleic acids by creating internal breaks. The other is a DNase I type protein, which catalyzes the hydrolysis of various bonds, e.g. C-O, C-N, C-C, and phosphoric anhydride bonds (Nishino and Morikawa 2002). Two T2 type ribonucleases were also found, which catalyze the two-stage endonucleolytic cleavage to nucleoside 3'-phosphates and 3'-phosphooligonucleotides with 2', 3'-cyclic phosphate intermediates (Luhtala and Parker 2010). These results confirmed the deoxyribonuclease and ribonuclease tests which showed positive results. To date, several deoxyribonucleases were isolated from fungi, but none of them have been connected to antifungal activity (Chen et al. 2012, Ye et al.

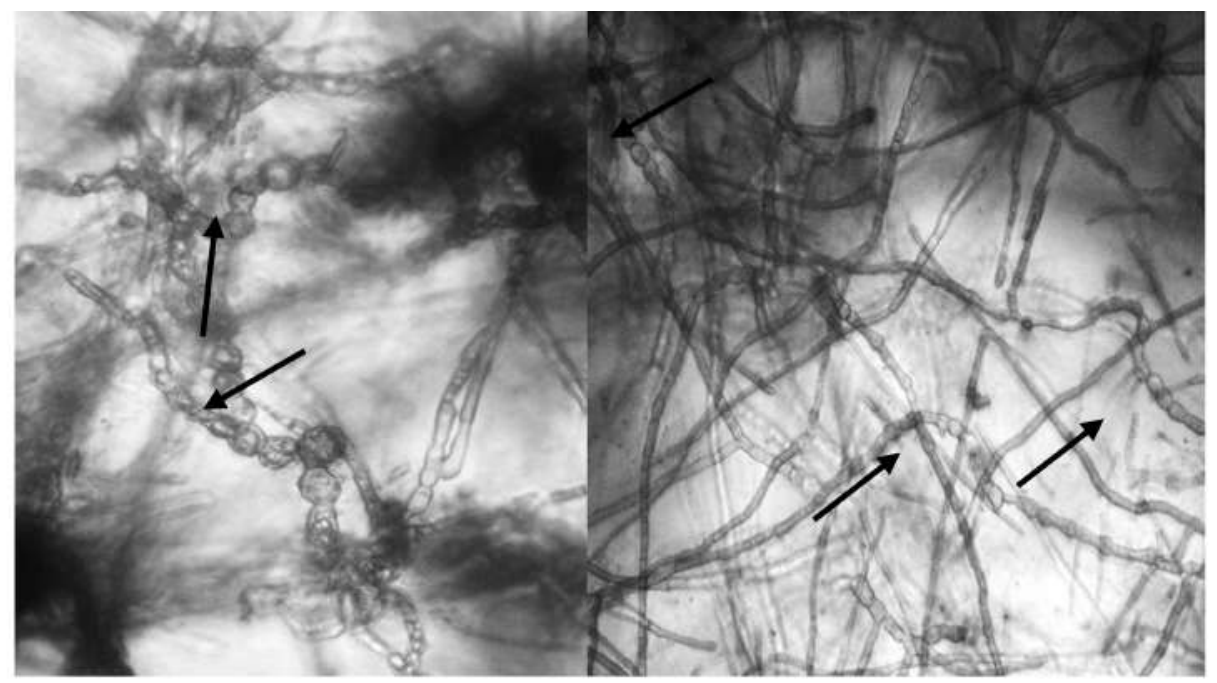

Figure 4. Collapsed hypha after inhibition assay. Photos taken directly from the wells with the Cytation $5^{\circledR}$ imaging reader. 
2005, Zhang et al. 2014). In other organisms, like plants, some deoxyribonucleases have shown antifungal qualities, like is the case of the deoxyribonuclease isolated from Asparagus officinalis seeds: it had a specific activity of $1584 \mathrm{U} / \mathrm{mg}$, a value higher than ours (table), and it exhibited antifungal activity towards cultures of $B$. cinerea but not towards $F$. oxysporum and Mycosphaerella sp. (Wang and $\mathrm{Ng}$ 2001). In another report a Pumpkin $2 \mathrm{~S}$ albumin from Putranjiva roxburghii showed DNase activity against both supercoiled and linear DNA and exerted antifungal activity against cultures of $F$. oxysporum (Tomar et al. 2014a).

Regarding ribonucleases, in a study performed by Zhang et al 2014, one ribonuclease was isolated from the mushroom Ramaria formosa, it was proved to have antifungal and antibacterial properties, and an activity in the crude extract of $45.2 \mathrm{U} / \mathrm{mg}$ was observed (Zhang et al. 2015), which compared to the results obtained in this study is $760 \mathrm{U} / \mathrm{mg}$ lower (table). Another case is the ribosome inactivating protein restrictocin from $A$. fumigatus and A. restrictus, which demonstrated suppressive activity towards the fungi Alternaria longipes, F. oxysporum, Colletotrichum gloeosporioides, Trichoderma viride and Paecilomyces variotii. However, its antifungal activity was highly dependent on the integrity of the disulfide linkage (Rao et al. 2015). One ribonuclease from Pleurotus sajor-caju also displayed antifungal activity over mycelial growth of $M$. arachidicola and F. oxysporum (Ngai and Ng 2004).

\section{Identification of proteins involved in glucan degradation and other glycoside hydrolases}

Accordingly, in our study we identified five glucanases, the particular presence of $\beta 1,3$ glucanase was confirmed by the Laminarin hydrolysis assay, which was composed of $\beta$ 1,3 glucan with 1,6 branches. Other glycoside hydrolases with different metabolic activities were found, plus other enzymes: one related to ATP and GTP metabolism and a ligase forming nitrogen-metal bonds. Glucans are a major component of the fungal cell wall. The endoglucanases are enzymes that catalyze several cleavages like $\beta$ 1-3, $\beta$ 1-4 and $\beta$ 1-6 D-Glucosidic linkages in glucans, so that cell lysis can occur as a result of the hydrolysis of glucans (Munro 2013). The endo- $\beta-1,3-$ glucanases are abundant proteins widely distributed in seed-plant species (Magnin-Robert et al. 2007, Wróbel-Kwiatkowska et al. 2004), fewer reports are found in fungi (Murphy et al. 2012, Sánchez et al. 2012). A protein called lentin from Lentinus edodes, with $\mathrm{N}$ terminal sequence resembling endoglucanase, repressed growth in $B$. cinerea, $M$. arachidicola and P. piricola (Ngai and Ng 2003).

Most of the proteins found in this study belong to the category of proteins related to carbohydrate metabolism, this can be due to the fact that $G$. lucidum was grown using a complex source of carbon, which could induce the production of enzymes that can degrade the compounds present in the cell wall of plants and fungi (figure 5 ).

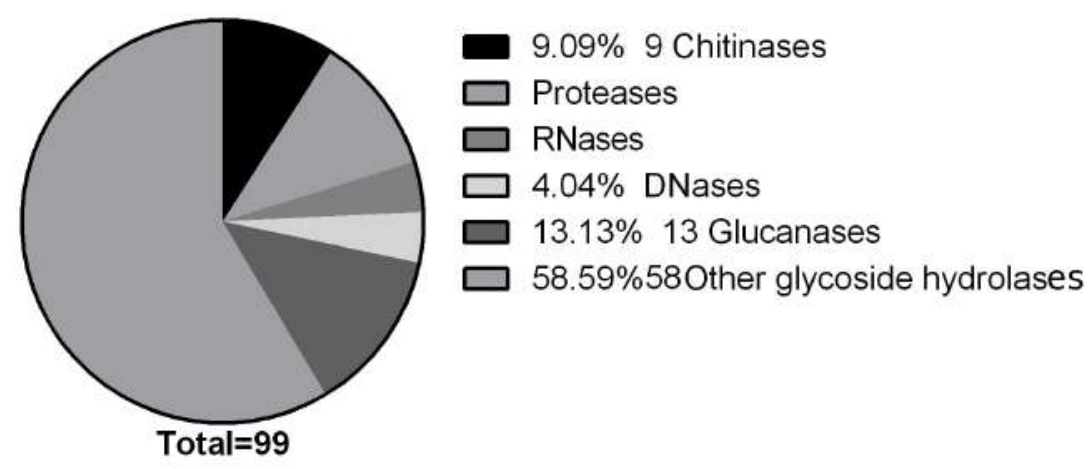

Figure 5. Pie chart depicting the identified proteins potentially related to antifungal activity of $G$. lucidum. Representation of proteins, identified by LC-MS/MS, classified according to their function gene ontology (GO) category and summarized in six subgroups. 
As shown in figure [3, to analyze the G. lucidum protein extract further, the 46 proteins selected were subjected to analysis by gene ontology (GO) ( $\mathrm{Yu}$ et al. 2015). A total of 46 proteins were classified across the GO and classified into 33 functional groups, with six involved in cellular components, twelve in molecular functions and eleven in biological processes. Among these GO classifications 'hydrolizing-O-compunds' (seventeen proteins), 'carbohydrate binding' (six proteins) and 'chitinase activity' (six proteins) were dominant.

The mix of enzymes analyzed in this study inhibited the mycelial growth of the phytopathogenic fungi $M$. fijiensis, and the antifungal potential of each of the enzymes is similar to that of previously reported antifungal proteins (Binder et al. 2011, Patil et al. 2013; Tan et al. 2013, Tomar et al. 2014b, Wang and Ng 2004). Thus, the production of these proteins could have important implications on disease management in banana crops.

In addition, the presence of potential antifungal proteins with different enzymatic activities contributes to the scanty literature related to proteins in this medicinal mushroom.

However, it is not clear yet which of them are responsible for this inhibitory growth activity, or if they have a synergic effect. In summary, this study confirmed the existence of many putative proteins predicted from the G. lucidum genome, enhancing the G. lucidum protein database (Yu et al. 2015) and showing their potential to be used in the development of a bioinput for the control of Black Sigatoka Disease in banana crops.

\section{CONCLUSIONS}

This study reports for the first time an analysis of G. lucidum active proteins against the fungus $M$. $f i$ jiensis. We demonstrated the expression of proteases, nucleases, chitinases, glucanases and other glycosyl hydrolases enzymes, and we successfully performed antifungal assays with them. Hence, G. lucidum is a potential candidate for the production of enzymes capable of interfering in the vital development of a phytopathogen fungus like $M$. fijiensis Morelet.

\section{ACKNOWLEDGMENTS}

We gratefully acknowledge the Universidad de Antioquia, the Biotechnology Laboratory and the Colombian Banana Producers Association- AUGURA, for their technical and financial support; to Dr. Oscar Alzate and the North Carolina Proteomic facility for their collaboration with the proteomic analysis; to Drs. Blanca Ortiz and Felipe Barrera from the GICIG (Cellular immunology and immunogenic Laboratory) for providing the Rotofor; and to Mónica Patricia Gómez for her help with the glucanase test.

\section{CONFLICTS OF INTEREST}

The authors express that there is no conflict of interest.

\section{REFERENCIAS}

Adams D. 2004. Fungal Cell Wall Chitinases and Glucanases. Microbiology, 150(7): 202935. doi:10.1099/mic.0.26980-0.

Ansor M, Abdullah N, Aminudin N. 2013. Anti-Angiotensin Converting Enzyme (ACE) Proteins from Mycelia of Ganoderma lucidum (Curtis) P. Karst. BMC Complementary and Alternative Medicine, 13(256): 18. doi:10.1186/1472-6882-13-256.

Arzate J, Aceves M, Dominguez M, Santos O. 2006. Antagonismo de Trichoderma Spp. Sobre Mycosphaerella fijiensis Morelet, Agente Causal de La Sigatoka Negra Del Plátano (Musa Sp.) in vitro e Invernadero. Revista Mexicana de Fitopatología, 24(002): 98104. https: //www.redalyc.org/articulo.oa?id $=61224203$

Ayala A, Colina M, Molina J, Vargas J, Rincón D, Medina J, Rosales L, Cárdenas H. 2014. Evaluación de la actividad antifúngica del quitosano contra el hongo Mycosphaerella fijiensis morelet que produce la sigatoka negra que ataca el plátano. Revista Iberoamericana de Polímeros, 15(6): 31238. http://www.ehu.eus/ reviberpol/pdf/NOV14/ayala.pdf

Banani H, Spadaro D, Zhang D, Matic S, Garibaldi A, Lodovica M. 2014. Biocontrol Activity of an Alkaline Serine Protease from Aureobasidium pullulans Expressed in Pichia pastoris against Four Postharvest Pathogens on Apple. International Journal of Food Microbiology, 182183: 18. doi:10.1016/j.ijfoodmicro.2014.05.001.

Binder U, Mojca B, Eigentler A, Meyer V, Marx F. 2011. The Aspergillus giganteus Antifungal Protein AFPNN5353 Activates the Cell Wall Integrity Pathway and Perturbs Calcium Homeostasis. BMC Microbiology, 11(209): 113. doi:10.1186/1471-2180-11-209.

Bradford M. 1976. A Rapid and Sensitive Method for the Quantitation of Microgram Quantities of Protein Utilizing the Principle of Protein-Dye Binding. Analytical 
Biochemistry, 72: 24854. doi:10.1006/abio.1976.9999.

Brzezinska M and Jankiewicz U. 2012. Production of Antifungal Chitinase by Aspergillus niger LOCK 62 and Its Potential Role in the Biological Control. Current Microbiology, 65: 66672. doi:10.1007/s00284-012-0208-2.

Ceballos I, Mosquera S, Angulo M, Mira J, Argel L, Uribe D, Romero M, Sergio Orduz S, Villegas V. 2012. Cultivable Bacteria Populations Associated with Leaves of Banana and Plantain Plants and Their Antagonistic Activity Against Mycosphaerella fijiensis. Microbial Ecology, 64(1): 113. doi:10.1007/s00248-012-0052-8

Cenibanano. 2009. Proyecto Especial Sigatoka. Medellín: AUGURA. Asociación de Bananeros de Colombia. General Technical Report. https://www.augura.com.co/ centro-documental/biblioteca-digital/

Chevalier F. 2010. Standard Dyes for Total Protein Staining in Gel-Based Proteomic Analysis. Materials, 3(10): 478492. doi:10.3390/ma3104784

Churchill A. 2011. Mycosphaerella fijiensis, the Black Leaf Streak Pathogen of Banana: Progress towards Understanding Pathogen Biology and Detection, Disease Development, and the Challenges of Control. Molecular Plant Pathology, 12(4): 30728. doi:10.1111/j.136437033.2010.010672

Clinical and Laboratory Standards Institute (CLSI). 2009. Reference Method for Broth Dilution Antifungal Susceptibility Testing of Filamentous Fungi; Approved Standard. 2nd ed. Wayne (USA): CLSI. 28(16):135. https: //clsi.org/media/1455/m38a2_sample.pdf

Cretoiu M, Kielak A, Al-Soud W, Sørensen S, Van Elsas J. 2012. Mining of Unexplored Habitats for Novel Chitinases - ChiA as a Helper Gene Proxy in Metagenomics. Applied Microbiology and Biotechnology, 94(5): 134758. doi:10.1007/s00253-012-4057-5.

Crowell A, Wall M, Doucette A. 2013. Maximizing Recovery of Water-Soluble Proteins through Acetone Precipitation. Analytica Chimica Acta, 796: 4854. doi:10.1016/j.aca.2013.08.005.

Dekroon R, Osorio C, Robinette J, Mocanu M, Winnik W, Alzate O. 2011. Simultaneous Detection of Changes in Protein Expression and Oxidative Modification as a Function of Age and APOE Genotype. Journal of Proteome Research, 10(4): 163244. doi:10.1021/pr1009788.

Erjavec J, Kos J, Ravnikar M, Dreo T, Saboti J. 2012. Proteins of Higher Fungi - from Forest to Application. Trends in Biotechnology, 30(5): 25973. doi:10.1016/j.tibtech.2012.01.004

Fabiola I, Oliveira R, Vaz C, Brugnari T, Castoldi R, Peralta R, Marques C. 2015. Proteases of Wood Rot Fungi with Emphasis on the Genus Pleurotus. BioMed Research International, 2015: 1-11. doi:10.1155/2015/290161.

Fernández F, Carbú M, El-Akhal M, Garrido C, González V, Cantoral J. 2011. Development of ProteomicsBased Fungicides: New Strategies for Environmentally Friendly Control of Fungal Plant Diseases. International Journal of Molecular Sciences, 12(1): 795816. doi:10.3390/ijms12010795.

Food and Agriculture Organization of the United Nations (FAO). 2011. Market and Policy Analyses of Raw Materials, Horticulture and Tropical (RAMHOT) Products
Team. Overview of World Banana Production and Trade. Rome: Food and Agriculture Organization of the United Nations.

Food and Agriculture Organization of the United Nations (FAO). 2014. Market and Policy Analyses of Raw Materials, Horticulture and Tropical (RAMHOT) Products Team. Banana Market Review and Banana Statistics 2012-2013. 2014. Rome: Food and Agriculture Organization of the United Nations. http://www.fao.org/3/ i3627e/i3627e.pdf

Frazier W and Rupp P. 1928. Studies on the Proteolytic Bacteria of Milk Ii. Action of Proteolytic Bacteria of Milk on Milk. Journal of Bacteriology, 16(1): 6578. https: //www.ncbi.nlm.nih.gov/pmc/articles/PMC533227/

Gabarro M, Gullon S, Vicente R, Caminal G, Mellado R, Lopez J. 2016. A Streptomyces lividans SipY Deficient Strain as a Host for Protein Production: Standardization of Operational Alternatives for Model Proteins. Journal of Chemical Technology and Biotechnology, 92(1): 21723. doi:10.1002/jctb.4933.

Hartl L, Zach S, Seidl V. 2012. Fungal Chitinases: Diversity, Mechanistic Properties and Biotechnological Potential. Applied Microbiology and Biotechnology, 93(2): 53343. doi:10.1007/s00253-011-3723-3.

Hegedüs N and Marx F. 2013. Antifungal Proteins: More than Antimicrobials. Fungal Biology Reviews, 26(1): 13245. doi:10.1016/j.fbr.2012.07.002.

Jijakli M and Lepoivre P. 1998. Characterization of an Exo-Beta-1,3-Glucanase Produced by Pichia anomala Strain K, Antagonist of Botrytis cinerea on Apples. Phytopathology, 88(4): 33543. doi:10.1094/PHYTO.1998.88.4.335.

Johanson A and Jeger M. 1993. Use of PCR for Detection of Mycosphaerella fijiensis and M. musicola, the Causal Agents of Sigatoka Leaf Spots in Banana and Plantain. Mycological Research, 97(6): 67074. doi:10.1016/S09537562(09)80145-7

Kalnitsky G, Hummel J, Dierks C. 1958. Some Factors Which Affect the Enzymatic Digestion of Ribonucleic Acid. Journal of Biological Chemistry, 234(6): 151216. http: //www.jbc.org/content/234/6/1512.long

Khalyfa A, Kermasha S, Khamessan A, Marsot P, Alli I. 1993. Purification and Characterization of Chlorophyllase from Alga (Phaeodactylum tricornutum) by Preparative Isoelectric Focusing. Bioscience, Biotechnology and Biochemistry, 57(3): 43337. doi:10.1271/bbb.57.433.

LaKunitz B. 1946. A Spectrophotometric Method for the Measurement of Ribonuclease Activity. Journal of Biological Chemistry, 164: 56368. http://www.jbc.org/content/ 164/2/563.short

Kunitz B. 1950. Crystalline Desoxyribonuclease; Isolation and General Properties; Spectrophotometric Method for the Measurement of Desoxyribonuclease Activity. The Journal of General Physiology, 33(4): 34962. doi:10.1085/jgp.33.4.349.

Laemmli U. 1970. Cleavage of Structural Proteins during Assembly of Head of BacteriophageT4. Nature, 227: 68085. doi:10.1038/227680a0.

LaMontagne E, Collins C, Peck S, Heese A, LaMontagne E, Collins C, Peck S, Heese A. 2016. Isolation 
of Microsomal Membrane Proteins from Arabidopsis thaliana. Current Protocols in Plant Biology, 1: 21734. doi:10.1002/cppb.20020.

Lapolla A, Fedele D, Reitano R, Concetta N, Seraglia R, Traldi P, Marotta E, Tonani R. 2004. Enzymatic Digestion and Mass Spectrometry in the Study of Advanced Glycation End Products/Peptides. Journal of the American Society for Mass Spectrometry, 15(4): 496509. doi:10.1016/j.jasms.2003.11.014.

Liang Z, Hseu R, Wang H. 1995. Partial Purification and Characterization of a 1 , 3-13-D-Glucanase from Ganoderma tsugae. Journal of Industrial Microbiology, 14: 59. doi:10.1007/BF01570058.

Luhtala N and Parker R. 2010. T2 Family Ribonucleases: Ancient Enzymes with Diverse Roles. Trends in Biochemical Sciences, 35(5): 25359. doi:10.1016/j.tibs.2010.02.002.

Magnin R, Trotel P, Quantinet D, Biagianti S, Aziz A. 2007. Biological Control of Botrytis cinerea by Selected Grapevine-Associated Bacteria and Stimulation of Chitinase and Beta-1,3 Glucanase Activities under Field Conditions. European Journal of Plant Pathology, 118: 4357. doi:10.1007/s10658-007-9111-2.

Manavalan T, Manavalan A, Thangavelu K, Heese K. 2015. Characterization of a Novel Endoglucanase from Ganoderma lucidum. Journal of Basic Microbiology, 55(6): 76171. doi:10.1002/jobm.201400808.

Marín D, Romero R, Guzmán M, Sutton T. 2003. Black Sigatoka: An Increasing Threat to Banana Cultivation. Plant Disease, 87(3): 20822. doi:10.1094/PDIS.2003.87.3.208.

Martínez H, Espinal C, Peña Y. 2005. La Cadena Del Banano En Colombia: Una Mirada Global de Su Estructura y Dinámica (1991-2005). Bogotá, Colombia: Ministerio de Agricultura y Desarrollo, Observatorio Agrocadenas. http://bibliotecadigital.agronet.gov.co/handle/ $11348 / 5874$

Montgomery D. 2012. Design and Analysis of Single-Factor Experiments: The Analysis of Variance. In: Montgomery DC and Runger GC editors. Applied Statistics and Probability for Engineers. 6th Ed. Hoboken (USA): John Wiley \& Sons, Inc. p. 463521.

Munro C. 2013. Chitin and Glucan, the Yin and Yang of the Fungal Cell Wall, Implications for Antifungal Drug Discovery and Therapy. Advances in Applied Microbiology, 83: 15-72. doi:10.1016/B978-0-12-407678-5.00004-0.

Murphy L, Cruys N, Delcomyn H, Baumann M, Olsen S, Borch K, Lassen S, Sweeney M, Tatsumi H, Westh P. 2012. Origin of Initial Burst in Activity for Trichoderma reesei Endo-Glucanases Hydrolyzing Insoluble Cellulose. Journal of Biological Chemistry, 287(2): 125260. doi:10.1074/jbc.M111.276485.

Ng T. B. 2004. Peptides and Proteins from Fungi. Peptides, 25: 105573. doi:10.1016/j.peptides.2004.03.013.

Ngai PH and Ng T. 2003. Lentin, a Novel and Potent Antifungal Protein from Shitake Mushroom with Inhibitory Effects on Activity of Human Immunodeficiency Virus-1 Reverse Transcriptase and Proliferation of Leukemia Cells. Life Sciences, 73: 336374. doi:10.1016/j.lfs.2003.06.023.

Ngai PH and Ng T. 2004. A Ribonuclease with Antimicrobial, Antimitogenic and Antiproliferative Activities from the
Edible Mushroom Pleurotus sajor-caju. Peptides, 25(1): 1117. doi:10.1016/j.peptides.2003.11.012.

Ngai PH, Zhao Z, Ng T. 2005. Agrocybin, an Antifungal Peptide from the Edible Mushroom Agrocybe cylindracea. Peptides, 26(2): 19196. doi:10.1016/j.peptides.2004.09.011.

Niño J, Correa Y, Mosquera O. 2011. In vitro Evaluation of Colombian Plant Extracts against Black Sigatoka (Mycosphaerella fijiensis Morelet). Archives of Phytopathology and Plant Protection, 44(8): 791803. doi:10.1080/03235401003672939.

Nishino T and Morikawa K. 2002. Structure and Function of Nucleases in DNA Repair: Shape, Grip and Blade of the DNA Scissors. Oncogene, 21(58): 902232. doi:10.1038/sj.onc.1206135.

Orlandelli R, de Almeida T, Alberto R, Polonio J, Azevedo J, Pamphile J. 2015. Antifungal and Proteolytic Activities of Endophytic Fungi Isolated from Piper hispidum Sw. Brazilian Journal of Microbiology, 46(2): 35966. doi:10.1590/S1517-838246220131042.

Osorio G. 2006. Evaluación de Hongos Endófiticos y Extractos Botánicos Para El Control de La Sigatoka Negra (Mycosphaerella fijinesis Morelet) En Banano [Tesis de Maestría]. [Turralba (Costa Rica)]. Centro agronómico tropical de investigación y enseñanza.

Paterson R. 2006. Ganoderma - a Therapeutic Fungal Biofactory. Phytochemistry, 67(18): 19852001. doi:10.1016/j.phytochem.2006.07.004.

Patil N, Waghmare S, Jadhav J. 2013. Purification and Characterization of an Extracellular Antifungal Chitinase from Penicillium ochrochloron MTCC 517 and Its Application in Protoplast Formation. Process Biochemistry, 48: 17683. doi:10.1016/j.procbio.2012.11.017.

Rao Q, Guo W, Chen X. 2015. Identification and Characterization of an Antifungal Protein, AfAFP Produced by Marine Derived Aspergillus fumigatus R9. Journal of Microbiology and Biotechnology, 25(5): 62028.

Rawlings N and Barrett A. 2014. Peptidases. 3rd ed. ELS. Academic Press.

Rodríguez A. 2010. Caracterización de Proteínas Con Actividad Antifúngica Producidas Por Penicillium chrysogenum [Tesis de doctorado]. [Extremadura, (España)]: Universidad de Extremadura.

Sánchez D, Sánchez S, Plasencia J. 2012. Fumonisin B1, a Toxin Produced by Fusarium verticillioides, Modulates Maize $\beta$-1,3-Glucanase Activities Involved in Defense Response. Planta, 235: 96578. doi:10.1007/s00425-011(1555-1).

Suarez I, Rosario R, Aguilar A, Clemente P, Cubano L, Serrano J, Schneider R, Martínez M. 2013. Anti-Tumor Effects of Ganoderma lucidum (Reishi) in Inflammatory Breast Cancer in in vivo and in vitro Models. PloS One, 8(2): e57431. doi:10.1371/journal.pone.0057431.

Thi N and Doucet N. 2016. Combining Chitinase C and N-Acetylhexosaminidase from Streptomyces coelicolor A3(2) Provides an Efficient Way to Synthesize N-Acetylglucosamine from Crystalline Chitin. Journal of Biotechnology, 220(2): 2532. doi:10.1016/j.jbiotec.2015.12.038

Tian M, Huitema E, Cunha L, Torto T, Kamoun 
S. 2004. A Kazal-like Extracellular Serine Protease Inhibitor from Phytophthora infestans Targets the Tomato Pathogenesis-Related Protease P69B. Journal of Biological Chemistry, 279(25): 2637077. doi:10.1074/jbc.M400941200.

Tomar S, Chaudhary N, Mishra P, Gahloth D, Kumar G, Selvakumar P, Kumar P and Sharma A. 2014 a. Purification, Characterisation and Cloning of a $2 \mathrm{~S}$ Albumin with DNase, RNase and Antifungal Activities from Putranjiva roxburghii. Applied Biochemistry and Biotechnology, 174(2): 47182. doi:10.1007/s12010-014-1078-9.

Tomar S, Nikhil K, Singh A, Selvakumar P, Partha Roy P, Sharma A. 2014 b. Characterization of Anticancer, DNase and Antifungal Activity of Pumpkin 2S Albumin. Biochemical and Biophysical Research Communications, 448(4): 34954. doi:10.1016/j.bbrc.2014.04.158.

United States Environmental Protection Agency (EPA). 2005. Mancozeb Facts. Washington, DC. EPA 738-F05-XX. https://www3.epa.gov/pesticides/chem_search/ reg_actions/reregistration/fs_PC-014504_1-Sep-05.pdf

Viveros J and Castaño J. 2006. Evaluación in vitro de extractos vegetales sobre Mycosphaerella fijiensis morelet. Agronomia, 14(1): 3750. https://www.redalyc.org/pdf/ 849/84916680041.pdf

Wang $\mathrm{H}$ and $\mathrm{Ng} \mathrm{T}$. 2001. Isolation of a Novel Deoxyribonuclease with Antifungal Activity from Asparagus officinalis Seeds. Biochemical and Biophysical Research Communications, 289(1): 12024. doi:10.1006/bbrc.2001.5963.

Wang $\mathrm{H}$ and $\mathrm{Ng} \mathrm{T}$. 2004. Eryngin, a Novel Antifungal Peptide from Fruiting Bodies of the Edible Mushroom Pleurotus eryngii. Peptides, 25(1): 15. doi:10.1016/j.peptides.2003.11.014.

Wang $\mathrm{H}$ and $\mathrm{Ng} \mathrm{T}$. 2006. Ganodermin, an Antifungal Protein from Fruiting Bodies of the Medicinal Mushroom Ganoderma lucidum. Peptides, 27(1): 2730. doi:10.1016/j.peptides.2005.06.009.

Wong J, Ng T, Cheung R, Ye X, Wang H, Lam S, Lin P, Chan Y, Fang E, Ngai P, Xia L, Ye X, Jiang Y, Liu F. 2010. Proteins with Antifungal Properties and Other Medicinal Applications from Plants and Mushrooms. Applied Microbiology and Biotechnology, 87(4): 122135. doi:10.1007/s00253-010-2690-4.

Wróbel M, Lorenc K, Starzycki M, Oszmiaski J, Kepczyska E, Szopa J. 2004. Expression of Beta-1,3-Glucanase in Flax Causes Increased Resistance to Fungi. Physiological and Molecular Plant Pathology, 65(5): 24556. doi:10.1016/j.pmpp.2005.02.008

Ye M, Liu J, Lu Z, Zhao Y, Liu S, Li L, Tan M, Weng X, Li W, Cao Y. 2005. Grifolin, a Potential Antitumor Natural Product from the Mushroom Albatrellus confluens, Inhibits Tumor Cell Growth by Inducing Apoptosis in vitro. FEBS Letters 579(16):343743. doi:10.1016/j.febslet.2005.05.013.

Yijie C, Jiang S, Jin Y, Yin Y, Yu G, Lan X, Cui M, Liang Y, Hon B, Wong C, Guo L, Sun H. 2012. Purification and Characterization of an Antitumor Protein with Deoxyribonuclease Activity from Edible Mushroom Agrocybe aegerita. Molecular Nutrition and Food Research, 56(11): 172938. doi:10.1002/mnfr.201200316.

Yike I. 2011. Fungal Proteases and Their Pathophys- iological Effects. Mycopathologia, 171(5): 299323. doi:10.1007/s11046-010-9386-2.

Yu G, Yin Y, Yu W, Liu W, Jin Y, Shrestha A, Yang Q, Ye X, Sun H. 2015. Proteome Exploration to Provide a Resource for the Investigation of Ganoderma lucidum. PloS One, 10(3): e0119439. doi:10.1371/journal.pone.0119439.

Zapata P, Rojas D, Ramirez D, Fernandez C, Atehortúa L. 2009. Effect of Different Light-Emiting Diodes on Mycelial Biomass Production of Ling Zhi or Reishi Medicinal Mushroom Ganoderma lucidum (W.Curt.:F.)P.Karst (Aphyllophoromycetideae). International Journal of Medicinal Mushrooms, 11(1): 9399. https://www.academia.edu/4615406/ Effect_of_Different_Light-Emitting_Diodes_on_Mycelial_ Biomass_Production_of_Ling_Zhi_or_Reishi_Medicinal_ Mushroom Ganoderma lucidum W. Curt. Fir. P. Karst. Aphyllophoromycetideae

Zhang Y, Liu Z, Ng T, Chen Z, Qiao W, Liu F . 2014. Purification and Characterization of a Novel Antitumor Protein with Antioxidant and Deoxyribonuclease Activity from Edible Mushroom Pholiota Nameko. Biochimie, 99(1): 2837. doi:10.1016/j.biochi.2013.10.016.

Zhang R, Tian G, Zhao Y, Zhao L, Wang H, Gong Z, Ng T. 2015. A Novel Ribonuclease with HIV-1 Reverse Transcriptase Inhibitory Activity Purified from the Fungus Ramaria formosa. Journal of Basic Microbiology, 55(2): 26975. doi:10.1002/jobm.201300876.

Zhiqiong T, Lin B, Zhang R. 2013. A Novel Antifungal Protein of Bacillus subtilis B25. SpringerPlus, 2(543): 16. doi:10.1186/2193-1801-2-543. 